\title{
GEOTECHNICAL ASPECTS OF THE SUMATRA EARTHQUAKE OF SEPTEMBER 30, 2009, INDONESIA
}

\author{
Ivan Gratchevi), Masyhur Irsyam ${ }^{\text {ii)}}$, IkUo Towhata ${ }^{\text {iii) }}$, \\ BaKhtiar MUin ${ }^{\text {iv) }}$ and Hasbullah Nawir ${ }^{\text {v) }}$
}

\begin{abstract}
This paper reports and discusses the results of a field survey conducted by a joint scientific group from Japan and Indonesia to assess the geotechnical aspects of the Sumatra earthquake $\left(M_{\mathrm{w}}=7.6\right)$ of September 30,2009 . The studied area included the Padang and Pariaman cities, where a number of buildings collapsed as a result of strong shaking, and a mountainous part of the Pariaman district, a place where massive landslides buried several villages, claiming more than 400 human lives. The main objective of the survey was to investigate the causes and mechanisms of catastrophic landslides; however, other geotechnical problems such as lateral spread and liquefaction were also addressed. Field observations indicated that the catastrophic landslides occurred on relatively gentle slopes, then mobilized into debris flows, and traveled several hundred meters from their points of origin. The failure surfaces developed along the boundary of highly weathered pumice tuff with more intact and less weathered bedrock. Data from a portable cone penetration test showed that the sliding material was rather weak, having SPT N-values in the range of 5-10. The results of the field survey suggested that the main cause of slope instability was high pore-water pressures that generated in the soil mass during the earthquake.
\end{abstract}

Key words: earthquake damage, geology, landslide, liquefaction, penetration test, slope stability (IGC: B2/B4)

\section{INTRODUCTION}

A powerful earthquake with a moment magnitude $\left(M_{\mathrm{w}}\right)$ of 7.6 struck the south-western coast of Sumatra, Indonesia, at 17:16:10 local time on September 30, 2009. The epicenter was located about $45 \mathrm{~km}$ northwest of Padang (Fig. 1), the capital of the West Sumatra province. The earthquake caused significant human and economic loss. According to The Kompas Newspaper (2009), more than 1100 people were confirmed dead in the Padang and Pariaman regions. Thousands of buildings, including several hotels, schools, shopping malls and hospitals were severely damaged during the earthquake. As many as 200 people died in the city's five-story Ambacang hotel (Fig. 2(a)) when the top floor collapsed due to strong shaking. The nearby Buaminang hotel (Fig. 2(b)) also suffered considerable deformation and was closed. In addition to the tremendous structural damage, the earthquake also triggered more than 1000 slope failures (UN OCHA, 2009). An extreme level of landslide damage was observed in a mountanious part of the Pariaman district, where massive landslides destroyed at least three villages, claiming more than 400 human lives. Rock falls and rock slides also blocked several major routes between Pariaman and Padang Panjang, causing lengthy traffic jams.

From October 30 to November 1, 2009, a joint research team from the University of Tokyo, Japan, and the Bandung Institute of Technology, Indonesia, conducted a field survey to assess the geotechnical damage caused by the earthquake. Although the focus of the survey was slope failures, other geotechnical problems, such as lateral spread and liquefaction, were also observed. During the first day, geotechnical problems and structural damage in Padang City caused by the earthquake were assessed (Fig. 1). On the following day, several catastrophic landslides in the Pariaman district were examined. On the final day of the survey, observations were made regarding the geotechnical characteristics of rock slides that occured along the main road between Pariaman and Padang Panjang (Fig. 1). This paper summarizes the field observations, provides characterization of the major types of landslides, and briefly describes the conditions in the area that contributed to slope instability. It also desribes observations of various geotechnical problems such as lateral spread and liquefaction that occured in Padang

i) Lecturer, Griffith School of Engineering, Centre for Infrastructure Engineering and Management, Griffith University, Australia (ivangratchev (a) gmail.com).

ii) Professor, Faculty of Civil and Environmental Engineering Institute Technology Bandung Jl., Indonesia.

iii) Professor, Department of Civil Engineering, University of Tokyo, Japan.

iv) Professor, Faculty of Civil and Environmental Engineering Institute Technology Bandung Jl., Indonesia.

v) Associate Professor, Faculty of Civil and Environmental Engineering Institute Technology Bandung Jl., Indonesia.

The manuscript for this paper was received for review on February 8, 2010; approved on December 7, 2010.

Written discussions on this paper should be submitted before November 1, 2011 to the Japanese Geotechnical Society, 4-38-2, Sengoku, Bunkyo-ku, Tokyo 112-0011, Japan. Upon request the closing date may be extended one month. 


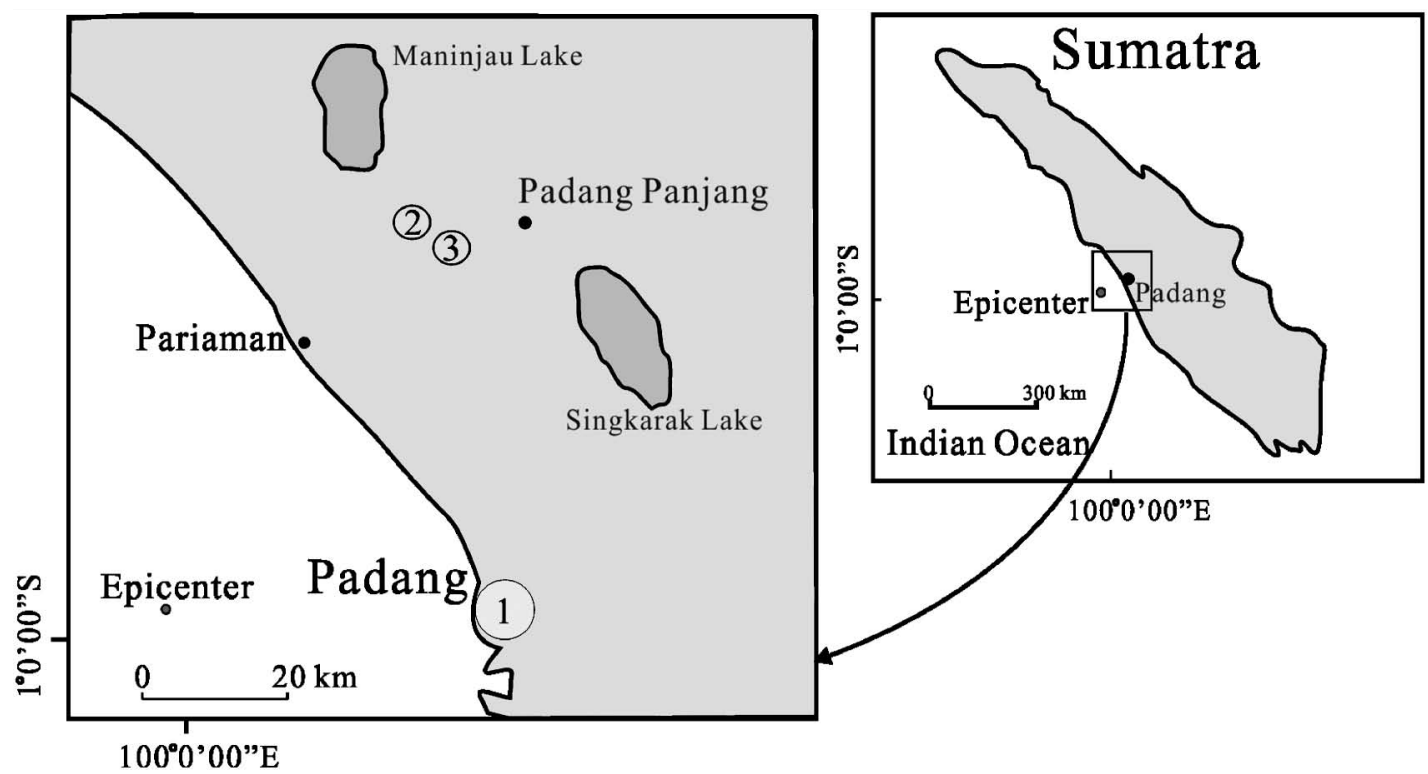

Fig. 1. A map of Sumatra showing the surveyed areas: (1) geotechnical and structural problems in Padang city, (2) catastrophic landslides in the Pariaman district and (3) rock slides along the road from Pariaman to Padang Panjang
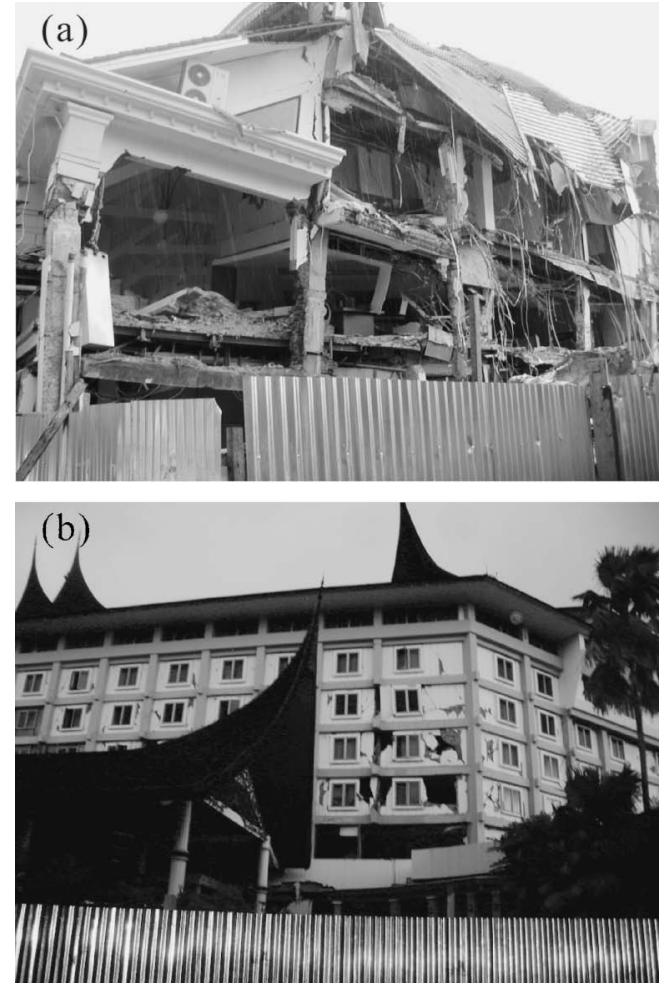

Fig. 2. A view of Ambacang hotel (a) and Buaminang hotel (b) that experienced considerable damage during the earthquake

City during the earthquake.

\section{LOCAL GEOLOGIC CONDITIONS}

The geologic characteristics of the mountainous part of the Pariaman district, where the majority of catastrophic landslides occurred, are shown in Fig. 3. According to a geologic map produced by the Geological Survey of In-

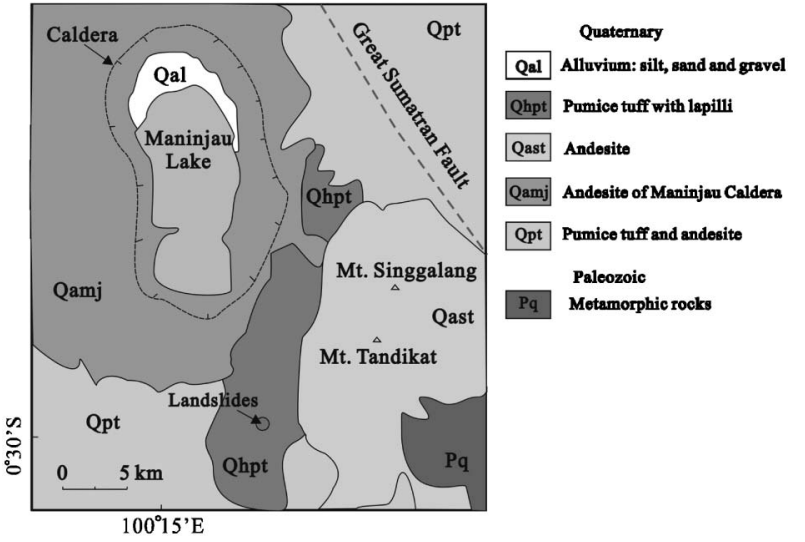

Fig. 3. Geologic characteristics of the studied area (Geologic outline is modified from Kastowo et al., 1996)

donesia (Kastowo et al., 1996), this area is primarily comprised of volcanic material such as andesite and pumice tuffs. The andesite rocks of Pleistocene (Qamj) are widely distributed in the western part of the area as shown in Fig. 3. They are considered to be the product of large Quaternary eruptions that formed the Maninjau caldera (Gasparon, 2005). The twin stratovolcanos, Tandikat and Singgalang, are located in the eastern part of the area (Fig. 3), where andesite of the late Pleistocene-Holocene (Qast) is spread out. The central part, including the area where the massive landslides were concentrated, primarily consists of Holocene pumice tuff (Qhpt) with lapili, ranging from 2 to $10 \mathrm{~cm}$ in diameter. Kastowo et al. (1996) noted that this pyroclastic material contains 3-10 $\%$ hornblende, hypersthene and (or) biotite. These rocks are characterized as weakly cemented material with fairly low durability, and thus highly susceptible to weathering. Alluvial deposits of silt, sand and gravel are widely 
spread along the coastal line of Padang City. According to Kastowo et al. (1996), the alluvium may include the remnants of pumice tuff.

\section{LOCAL SEISMICITY}

There are two seismically active zones around Sumatra Island, namely, the subduction zone and transform fault zone, which are considered to be the main sources of earthquakes (Aydan, 2008). The former is typically associated with the convergent boundary where the Indo-Australian and Philippine Sea plates subduct underneath the Euro-Asian (Sunda) plate. The latter includes the frontal arc area of Sumatra Fault, where earthquakes occur as a result of strike slip movement along clearly defined faults (Irsyam et al., 2008). The aforementioned tectonic features make Sumatra one of the most seismically active places in the world, such that strong earthquakes are frequently occurring phenomena, causing considerable economic damage almost every year. Recent data show that since the devastating 2004 Aceh earthquake $\left(M_{\mathrm{w}}=9.3\right)$ which resulted in the deaths of more than 200,000 people, six powerful earthquakes with a moment magnitude of greater than seven have stricken the island in the following four years (Aydan, 2008).

The earthquake of September 30, 2009 occurred as a result of oblique-thrust faulting near the subduction interface plate boundary at the depth of $80 \mathrm{~km}$ (USGS, 2009). It is noted that the focus of this earthquake was much deeper than that of the typical subduction earthquake, which is generally less than $50 \mathrm{~km}$. The strong shaking that continued for about $15 \mathrm{sec}$ produced a peak horizontal ground acceleration of $0.3 \mathrm{~g}$ along the coast line between Padang and Pariaman (USGS, 2009). The ground motion record obtained at the University of Andalas, which is located about $15 \mathrm{~km}$ northeast of Padang, is given in Fig. 4.

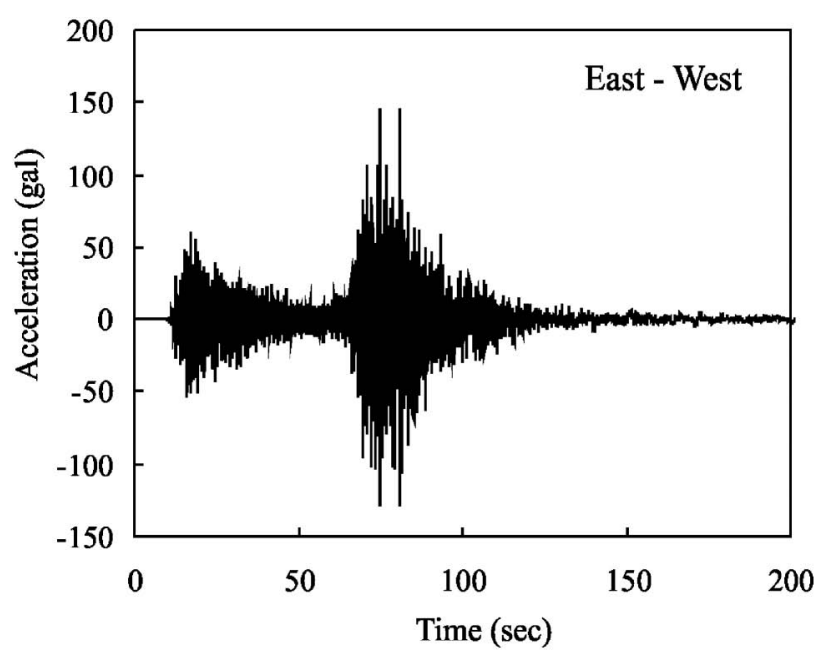

Fig. 4. Acceleration record obtained during the Sumatra earthquake of September 30, 2009, at the University of Andalas located about $15 \mathrm{~km}$ east of Padang City

\section{PRECIPITATION CHARACTERISTICS}

The earthquake of September 30, 2009, occurred at the beginning of a rainy season that typically starts in October and lasts until March. Rainfall data presented by Baum et al. (2007) show that the average precipitation rate throughout a year is about $150 \mathrm{~mm}$ per month, with the peak of $600 \mathrm{~mm}$ in October. Such a high rate of rainfall seems to be one of the major causes of the numerous landslides on Sumatra. Although no significant precipitation was recorded on the day before September 30, 2009 (according to eyewitnesses, heavy rainfall started $30 \mathrm{~min}$ after the event), it is still reasonable to assume that the soil mass of the failed slopes was well saturated prior to the earthquake. This hypothesis is derived from accounts of local people who recalled that significant amounts of groundwater "gushed out" from the base of failed slopes in Lubuk Laweh immediately after the earthquake occurred.

\section{RESULTS OF SURVEY}

\section{Slope Failures}

The most common types of slope failures triggered by the earthquake were massive catastrophic landslides that had significant runout distances and small to medium size rock slides. The former was commonly found in highly weathered pyroclastic rocks in the area marked as 2 in Fig. 1, while the latter was mainly observed on relatively steep slopes along the road connecting Pariaman with Padang Panjang (marked as 3 in Fig. 1). A brief description of each type is given below.

\section{Catastrophic Landslides in Highly Weathered Volcanic Material}

This catastrophic type of failure was observed on the southern slopes of Mt. Tandikat of the most severely-hit Pariaman District, where at least three adjacent villages, namely Palokoto, Cumanak, and Lubuk Laweh were leveled off by landslides, resulting in the deaths of more than 400 people. According to eyewitnesses, massive landslides occurred simultaneously at different locations, and traveled rapidly several hundred meters, thus leaving virtually no time for local people to escape. The situation was made worse by the fact that rescue work was hampered by heavy tropical rain that started about 30 minutes after the earthquake.

In Palokoto village, a large landslide destroyed a school, claiming 41 human lives (Fig. 5). The landslide mass, which consisted of volcanic material, mostly pumice tuff, traveled more than $500 \mathrm{~m}$ onto flatter areas with an inclination of 6-8 degrees, covering a territory of about $25,000 \mathrm{~m}^{2}$. A Laser Rangefinder, a device that allows precise measurement of the degree of slope inclination, was used to evaluate a dip of the failure plane, which was found to be 25-30 degrees (Fig. 5(c)). The high velocity of the landslide and the considerable runout distance suggest that the sliding mass had a relatively low resistance to motion. The maximum thickness of debris 


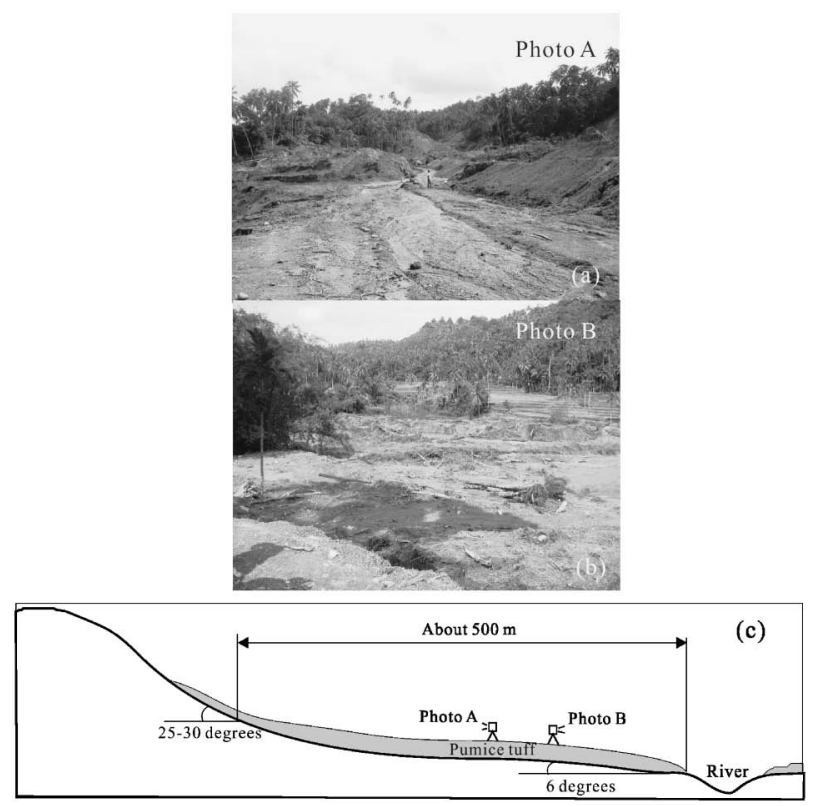

Fig. 5. A view of the large landslide in Palokoto: (a) the source area (Photo A), (b) the debris material at the toe (Photo B) and (c) schematic cross-section of the landslide site

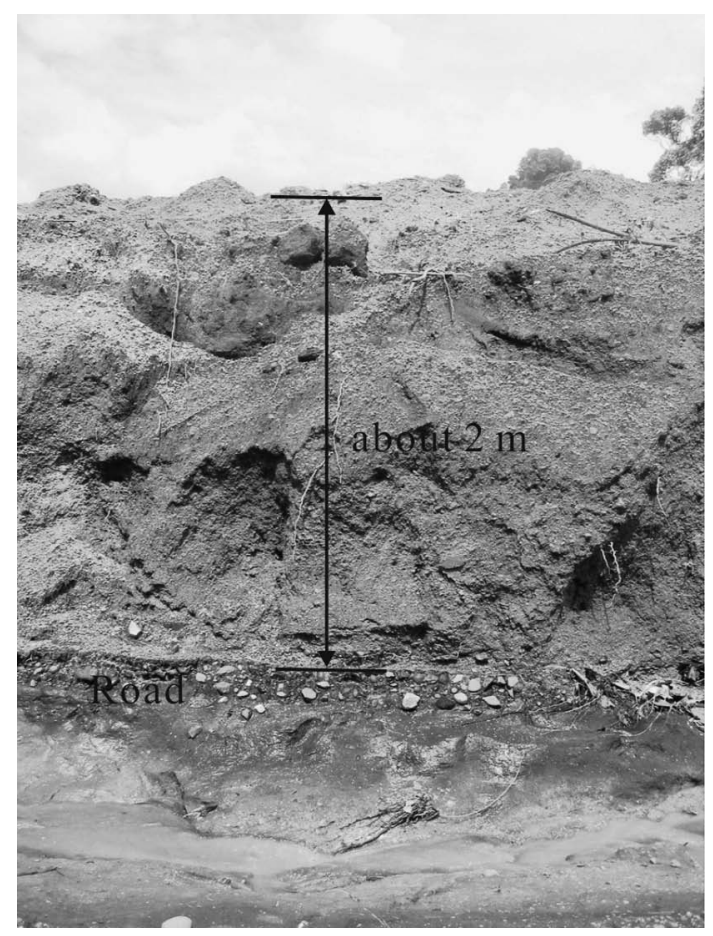

Fig. 6. The debris material at Palokoto village

material was estimated to be $2 \mathrm{~m}$ (Fig. 6). Smaller slides similar to the one shown in Fig. 7 occurred on the same and adjacent slopes, raising the total volume of debris material to about $40,000 \mathrm{~m}^{3}$. The survey showed that some parts of sliding mass and debris were still located on planes inclined in the range of 6-15 degrees, thus posing a continuing hazard to the local community. It is believed that such loose and disaggregated material can be easily and rapidly eroded during future intense, prolonged rain-

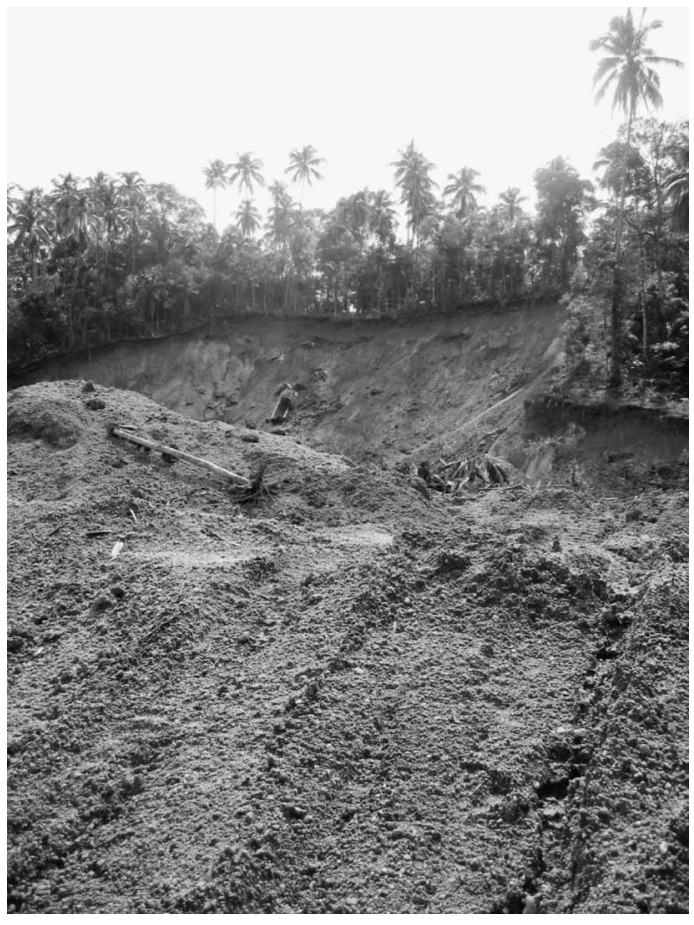

Fig. 7. A view of another slide at Palokoto that occurred about $300 \mathrm{~m}$ away from the main failure

fall. As a result, the stability of sliding mass would have been significantly undermined, leading to further downward movement.

Lubuk Laweh is located about $1 \mathrm{~km}$ north of the Palokoto village. The disaster that hit this hamlet caught the attention of the international media due to the extremely high death toll. According to a government report, about 400 people who were attending a wedding ceremony there were buried by landslides that plummeted down from the surrounding mountains (Fig. 8). It is believed that the landslides mobilized into debris flows because of the high degree of soil saturation at the time of the earthquake, and traveled several hundred meters (400-500 m). The landslide mass also blocked the local river for more than two hours, posing a significant flood threat. It is interesting to note that, similar to the Palokoto landslide, the inclination of the area from the bases of failed slopes to the river was gentle, in the range of 8-10 degrees. According to eyewitnesses, during the earthquake, groundwater first emerged at the base of slopes in the form of springs, and was then followed by a massive mudflow.

Two large slides also occurred on the opposite bank of the river (Fig. 8) where the landslide mass slid downward several meters. The failure appeared to be rotational in movement, with an inclination of the failure plane of 20-25 degrees. The material involved in sliding was highly weathered pumice tuff. The thickness of the sliding mass was estimated to be $5-10 \mathrm{~m}$. A portable dynamic cone penetration test was performed near the scarp (Fig. 9) to obtain estimates of the strength of soil. Results of the test will be described in the following sections. 


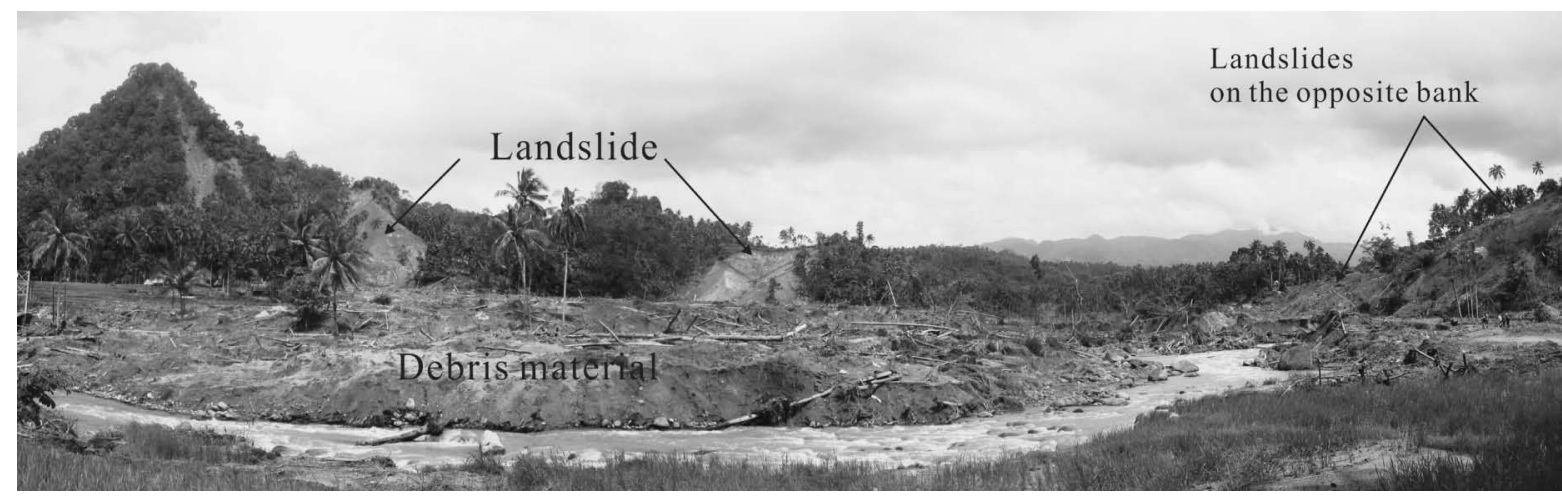

Fig. 8. A view of landslide sites and debris material at Lubuk Laweh (in this picture the river flows from the right to the left)

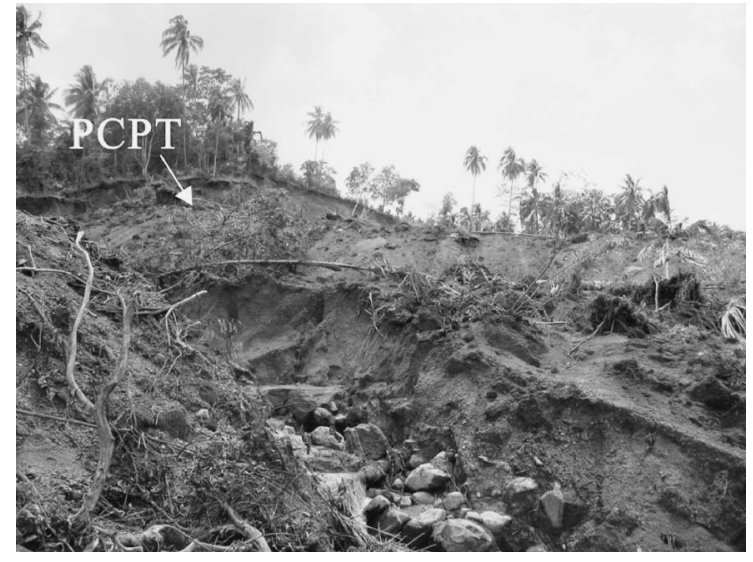

Fig. 9. A view of landslide that occurred on the opposite bank of the river at Lubuk Laweh. PCPT denotes the place where the portable cone penetration test was performed
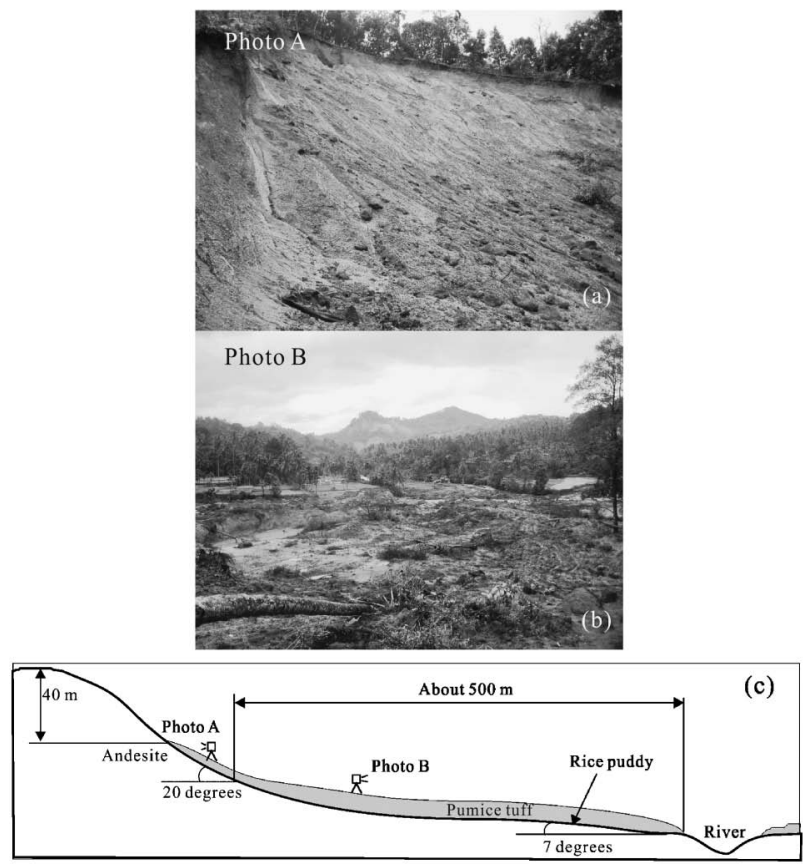

Fig. 10. A view of large landslide near Makalak village: (a) the source area (Photo A), (b) the debris material at the toe (Photo B) and (c) a schematic cross-section of the landslide site

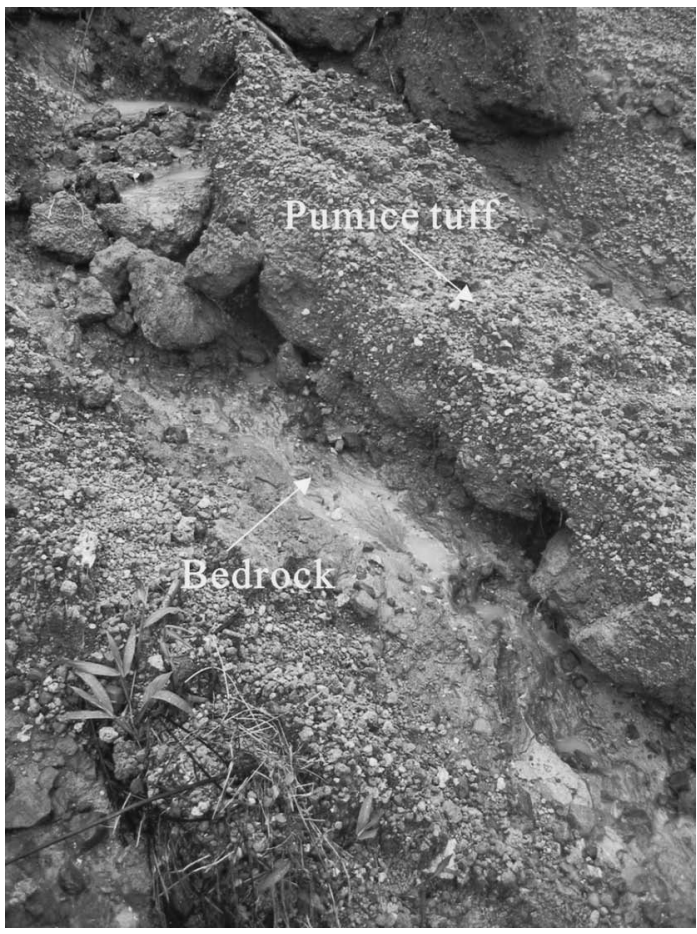

Fig. 11. A view of the failure plane of the Makalak landslide

A massive landslide with a volume of more than $200,000 \mathrm{~m}^{3}$ was observed near Makalak village. Local people recalled that the slide was rapid in motion, resulting in the death of a family and a destroyed house. This landslide has a length of $500 \mathrm{~m}$, a width of more than 100 $\mathrm{m}$, and an estimated average thickness of $7 \mathrm{~m}$ (Fig. 10). The failure plane, which is inclined at about 20 degrees (Fig. 10(c)), developed along the boundary of highly weathered volcanic material with less weathered andesite (Fig. 11). It is noted that the sliding mass plunged onto a rice paddy, a fact that might have also contributed to the high velocity of the debris flow. It is believed that the saturated rice paddy served as a lubricated surface on which the sliding mass moved with little resistance to motion.

\section{Rock Slides}

A few medium to small size rock slides triggered by the 


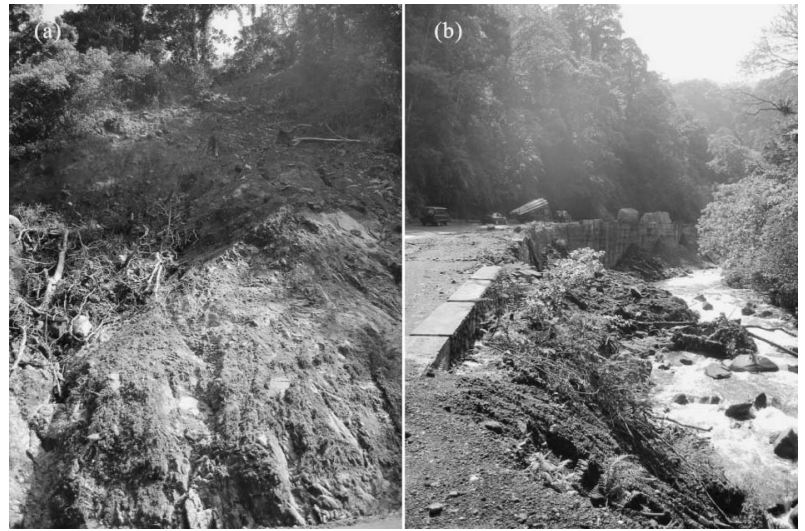

Fig. 12. A view of rock slide at Salaing: the unstable slope (a) and the debris material that plunged in the river (b)

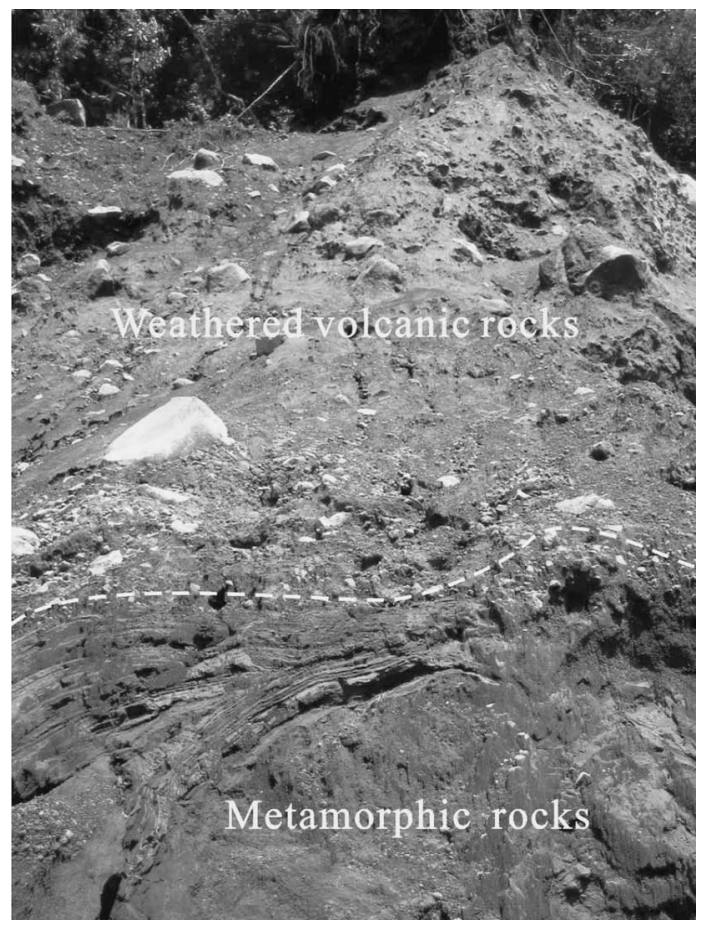

Fig. 13. Geologic characteristics of rock falls

earthquake were observed along the road connecting Pariaman with Padang Panjang (Fig. 1). Figure 12 shows a slope failure that blocked the road at a place called Salaing, suspending the traffic for 2 days. Huge rocks with a diameter of $3 \mathrm{~m}$ and weathered colluvium were the material that cascaded down the slope and plunged into the river (Fig. 12(b)). The slope inclination was measured to be about 45 degrees and the height was estimated to be approximately $70 \mathrm{~m}$. The geologic characteristics of such rock slides can be described as follows: the top part of the slope is comprised of volcanic material (andesite or basalt) while the toe part is typically represented by metamorphic rocks (Fig. 13).

It seems that the main cause of rock slides was weathering; however, at the time of the survey, it was not clear whether the road construction of previous years affected

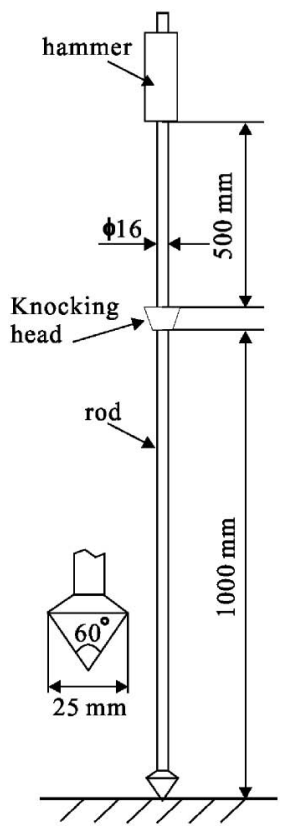

Fig. 14. Portable dynamic cone penetrometer

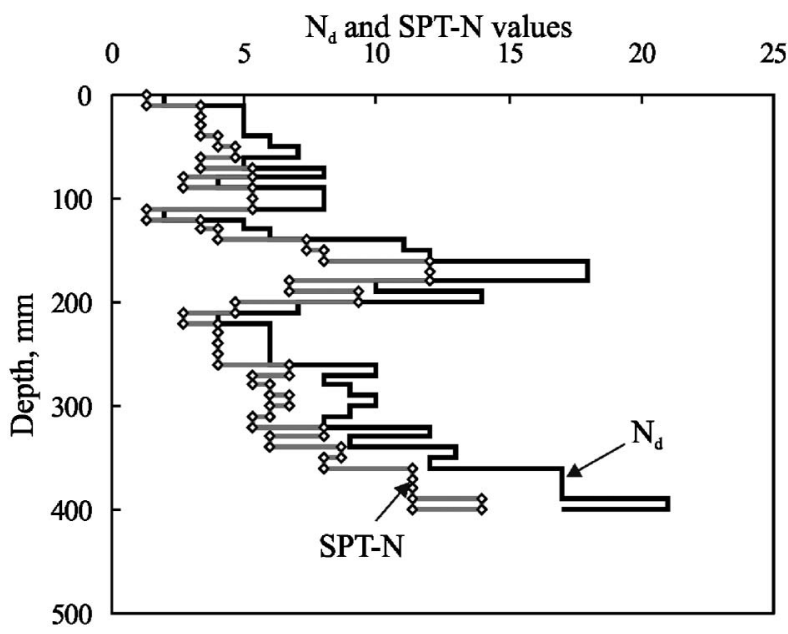

Fig. 15. Results of dynamic cone penetration test. $\mathbf{N}_{d}$-measured values during testing, SPT $\mathrm{N}$-corresponding values of standard penetration test

the slope stability.

\section{Results of Dynamic Cone Penetration Test}

A portable dynamic cone penetration test (JGS 1433-1995) was performed at a landslide site to obtain estimates of the strength of soil. The penetrometer (Fig. 14) has a conical tip with a $4.9 \mathrm{~cm}^{2}$ area and $60^{\circ}$ apex angle. It is driven in the ground by repeated blows of a $5 \mathrm{~kg}$ hammer released from a height of $50 \mathrm{~cm}$. The number of blows required to achieve $10 \mathrm{~cm}$ of penetration is taken as the cone penetration resistance, Nd. Several correlations between $\mathrm{Nd}$ and the standard penetration test (SPT) $\mathrm{N}$ values have been proposed, depending on the type of soil. It is recommended that for landslide studies, when this test is performed on steep slopes, the correlation of $\mathrm{Nd}=$ 
$1.5^{*} \mathrm{~N}$ should be used.

A penetration test was conducted on the top of the sliding mass near the scarp area of the landslide shown in Fig. 9. Figure 15 shows the variation of measured $\mathrm{Nd}$ values with depth and the corresponding SPT N-values. From these data it can be inferred that the soil was weak: the $\mathrm{N}$-values were typically in the range of 3 to 7 . According to the Field Investigation Handbook of the Japanese Geotechnical Society (2004), granular soil with such penetration characteristics can be described as loose material with a friction angle of about 30 degrees.

The penetration data also provide a basis for estimation of the undrained strength of soil after the failure. Seed and Harder (1990) and Stark and Mesri (1992) noted that for liquefied soils with SPT N-values in the range of $7-10$, the ratio between the undrained shear strength and initial effective vertical stress could be as low as 0.15-0.20, which correlates with the friction angle of about $8.5-11.5^{\circ}$. This indicates that the strength of pumice tuff could significantly drop during strong shaking as a result of high pore-water pressures generation.

\section{Discussion on the Causes of Catastrophic Landslides}

Field observations, numerous accounts of eyewitnesses, and the penetration test data suggest that several factors, including the geologic conditions and the strong ground motion produced by the earthquake, may have contributed to the slope instability. In particular, the sur- vey revealed that the catastrophic landslides were concentrated in a small area with relatively similar geologic conditions. The failure planes developed in highly weathered pumice tuff, which appears to be the dominant lithological unit in that region. From previous case studies (Fukuoka et al., 2004; Gratchev and Towhata, 2010), it can be inferred that, when subjected to earthquake loading, pumice tuff becomes rather susceptible to the generation of high excess pore-water pressures. As a result, the shear resistance may drastically decrease, leading to slope instability. Sassa et al. (2004) noted that the process of grain crashing that occurs in weathered pumice and tuff during strong shaking may be an additional factor that would determine the high velocity and long run-out distance of the landslides.

In case of the Makalak landslide (Fig. 10), the long distance and high velocity can also be attributed to the fact that the landslide slid on a rice paddy, which served as a lubricated surface on which the sliding mass moved with little resistance to motion.

Finally, it should be mentioned here that although rapid, long-traveling landslides have been the topic of several studies, predicting their occurrence still remains extremely difficult for both researchers and geotechnical engineers. However, properly educating local people about the causes of landslides and possible preventive measures can be useful for saving human lives.

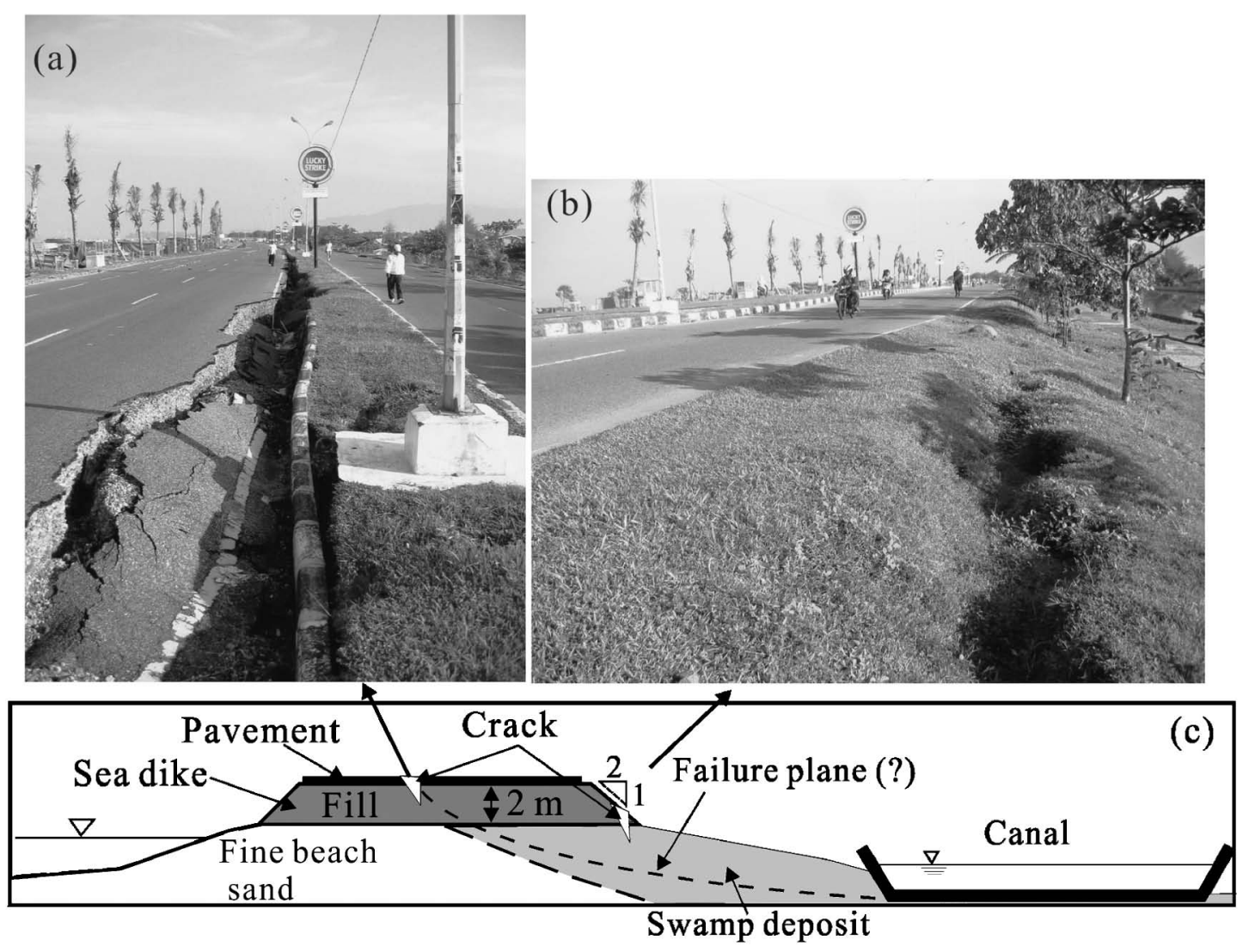

Fig. 16. Lateral spread observed at sea dike. The $1 \mathrm{~m}$ crack in the middle of the road (a), local failure of the road embankment (b) and schematic interpretation of the failure (c) 


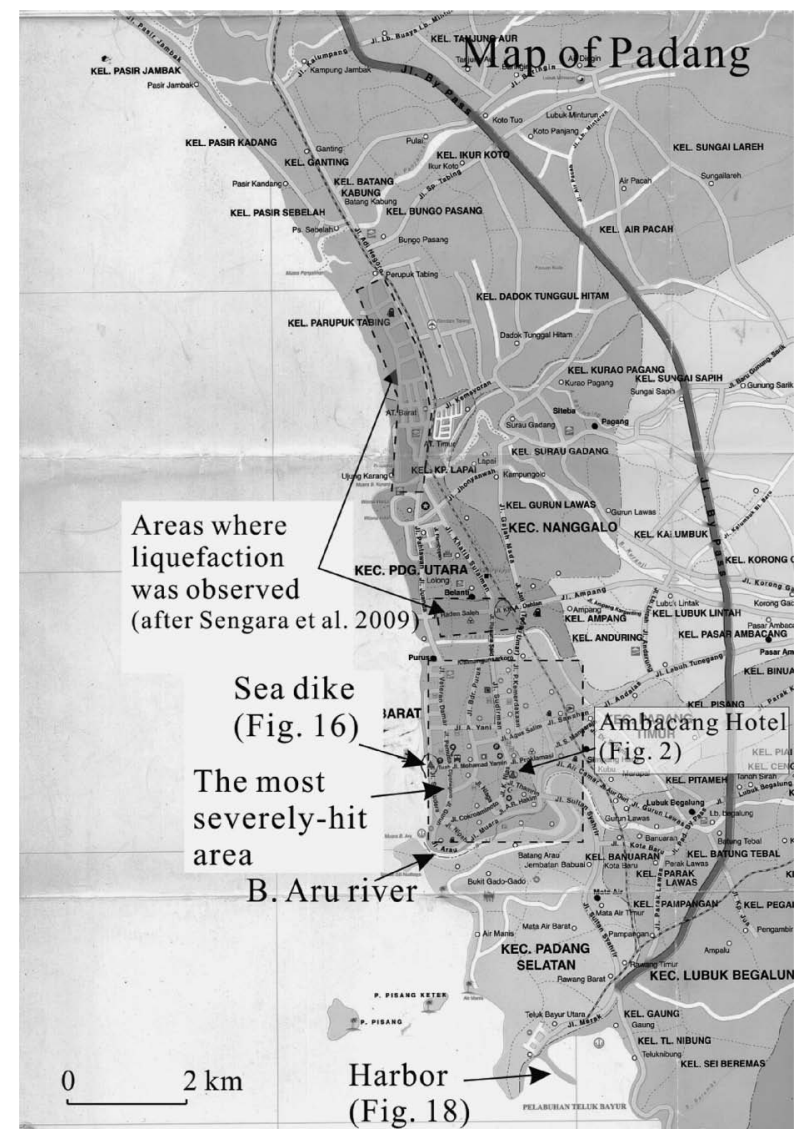

Fig. 17. A map of Padang city showing the areas which were the most severely affected by the earthquake

\section{OTHER GEOTECHNICAL PROBLEMS IN PADANG CITY}

In addition to landslides, other geotechnical aspects of the damage caused by the earthquake were also assessed during the survey. Strong ground motion produced by the earthquake caused significant deformation of a sea dike in Padang (Fig. 16). Observations showed that a stretch of the road (about $200 \mathrm{~m}$ ) was ruptured by numerous cracks, which appeared at several locations but primarily in the section of the road that was augmented five years ago to permit more traffic. Unlike the original part of the embankment that stood on fine beach sand, the new lane was placed on the "swamp" deposits as schematically shown in Fig. 16(c). It appears that during the earthquake, the soft swamp soil experienced significantly larger deformations than the fine sand, resulting in the formation of several big cracks and local failures.

Local soil conditions seem to have played an important role in the stability of houses and institutional buildings during the earthquake in Padang. It was observed that the most severely-hit area with the largest structural damage was located in the vicinity of the B. Aru river (Fig. 17). It is likely that soft alluvial deposits caused considerable amplification of the ground motion, resulting in larger deformations. It is noted that in Sumatra, a

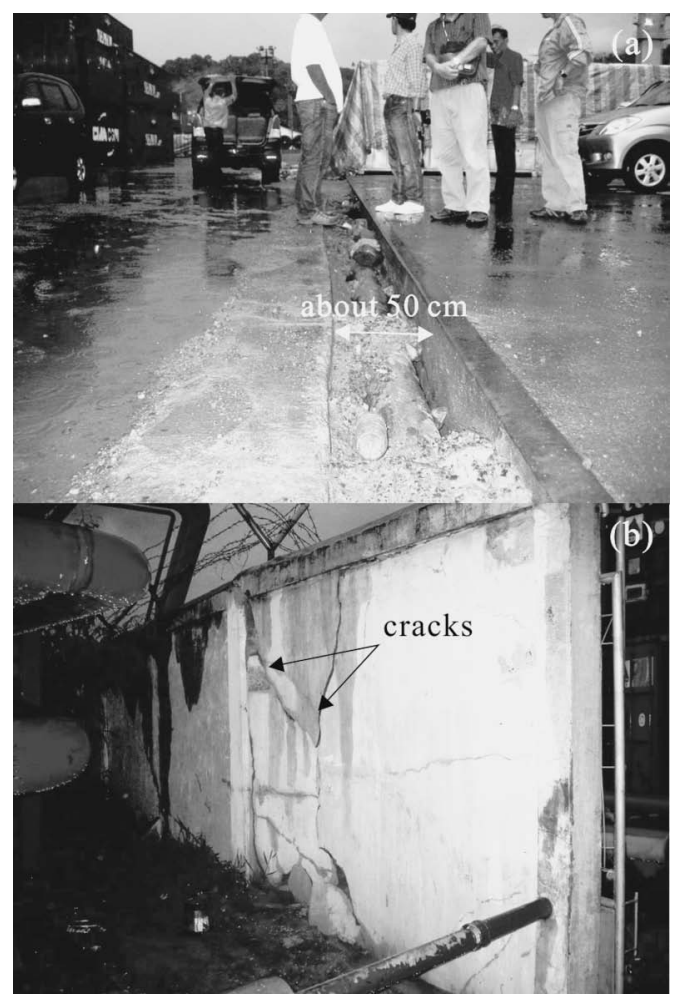

Fig. 18. Minor damage was observed at the Padang Harbor: (a) lateral deformation of the platform and (b) cracks on the wall

construction permit does not require geotechnical investigation prior to construction, and as a result, there is no information regarding soil conditions available for public use. For the same reason, it remains unclear whether the tectonic features of the area, including the local faults, had a significant impact on the extent of damage caused by the earthquake.

Minor damage was also observed at the Padang Harbor, which is located in the south part of the city (Fig. 17). Ground shaking produced a $50 \mathrm{~cm}$ gap between the platform that stood on piles and the filling (Fig. 18(a)). A few cracks also appeared on the wall that separated the platform from the piers (Fig. 18(b)).

\section{SUMMARY AND CONCLUSIONS}

A field survey was conducted by a joint research team from the University of Tokyo and the Bandung Institute of Technology to assess the geotechnical and structural damage caused by the Sumatra earthquake of September 30. The studied areas include Padang and Pariaman, two big cities that were the most severely hit by the seismic activity. A few villages located in Pariaman District were also surveyed to assess the slope stability problems caused by the earthquake.

The focus of the survey was mainly directed towards investigating the geotechnical aspects of the earthquaketriggered landslides, including their geologic, geomorphological and geotechnical characteristics. The survey revealed that the catastrophic landslides in Palokoto, Lubuk Laweh and Makalak had a number of similar fea- 
tures which are summarized below:

The landslides originated on slopes with an inclination of 20-25 degrees, mobilized into debris flows, and then traveled long distances (about 400-500 m) on the flatter surfaces with a dip of 8-10 degrees.

The landslide mass consisted mainly of highly weathered pumice tuff. In the case of the Makalak landslide, it was found that the layer of pumice tuff was underlain by hard volcanic bedrock.

The main cause of these landslides seems to have been earthquake-induced high pore-water pressures which significantly reduced the strength of soil, undermining the stability of slopes.

The results of a portable cone penetration test revealed that the soil material from the landslide mass was rather weak, with SPT N-values in the range of 5-10.

Other geotechnical problems encountered during the survey were lateral spreading in Padang. A sea dike experienced significant deformation as a result of strong shaking and unfavorable soil conditions. Local soil conditions seem to have been a contributing factor to the collapse of houses and buildings in certain areas of Padang. It was observed that the most damage occurred in the area adjacent to the river where soft alluvial deposits were distributed.

\section{ACKNOWLEDGEMENTS}

The authors acknowledge the help of Mr. Delfebriyadi and Mr. Agus Himawan of Andalus University, Sumatra, Indonesia.

\section{REFERENCES}

1) Aydan, O. (2008): Seismic and Tsunami Hazard Potentials in Indonesia with a special emphasis on Sumatra Island, Journal of The School of Marine Science and Technology, Tokai University, 6(3), 19-38.

2) Baum, A., Rixen, T. and Samiaji, J. (2007): Relevance of peat draining rivers in central Sumatra for the riverine input of dissolved organic carbon into the ocean estuarine, Coastal and Shelf Science, 73(3-4), 563-570.

3) Fukuoka, H., Wang, G., Sassa, K., Wang, F. and Matsumoto, T. (2004): Earthquake-induced rapid long-traveling flow phenomenon: May 2003 Tsukidate landslide in Japan, Landslides, 1(2), 151-155.

4) Gasparon, M. (2005): Quaternary volcanicity, Sumatra: Geology, Resources and Tectonic Evolution, Geological Society Memoir, 31, 120-130.

5) Gratchev, I. and Towhata, I. (2010): Geotechnical characteristics of volcanic soil from seismically-induced Aratozawa landslide, Japan, Landslides, 7, 503-510.

6) Irsyam, M., Dangkua, D. T., Hendriyawan, Hoedajanto, D., Hutapea, B. M., Kertapati, E. K., Boen, T. and Petersen, M. D. (2008): Proposed seismic hazard maps of Sumatra and Java islands and microzonation study of Jakarta city, Indonesia, J. Earth Syst. Sci., 117(2), 865-878.

7) JGS 1433-1995, Method for portable dynamic cone penetration test.

8) JGS (2004): Standard penetration test, Japanese Standards for Geotechnical and Geoenvironmental Investigation Methods, 264.

9) Kastowo, Leo G. W., Gafoer, S. and Amin, T. C. (1996): Geological Map of the Padang Quadrangle, Sumatra, Geological Research and Development Center, Indonesia.

10) Kompas (2009): Liputan Khusus, (http://www.kompas.com/ lipsus092009/subduksi).

11) Sassa, K., Fukuoka, H., Wang, G. and Ishikawa, N. (2004): Undrained dynamic-loading ring-shear apparatus and its application to landslide dynamics, Landslides, 1, 7-19.

12) Seed, H. B. and Harder, L. F. (1990): SPT-based analysis of cyclic pore pressure generation and undrained residual strength, Proc. H.B. Seed Memorial Symp., Canada, 2, 351-376.

13) Sengara, I. W., Putra, Hendri. G., Hakam, A., Sumiartha, P. and Abuhuroyroch, K. M., (2009): Reconnaissance survey findings and some geotechnical earthquake engineering aspects of West Java and West Sumatra disasters, ISGE 13th Annual Meeting, Bali.

14) Stark, T. D. and G. Mesri (1992): Undrained shear strength of liquefied sands for stability analysis, Journal of Geotechnical Engineering, 118(11), 1727-1747.

15) United Nations Office for the Coordination of Humanitarian Affairs (UN OCHA) (2009): Indonesia Earthquake Situation Report \#4, October 3, 2009.

16) USGS (2009): Magnitude 7.6-Southern Sumatra Earthquake, (http://earthquake.usgs.gov/eqcenter/recenteqsww/Quakes/ us2009mebz.php). 